\title{
Breastfeeding and vitamin D
}

Ju Sun Heo, MD, PhD ${ }^{1}$, Young Min Ahn, MD, PhD², Ai-Rhan Ellen Kim, MD, PhD ${ }^{3}$, Son Moon Shin, MD, PhD ${ }^{4}$; for the Korean Society of Breastfeeding Medicine

${ }^{1}$ Department of Pediatrics, Anam Hospital, Korea University College of Medicine, Seoul, Korea; ${ }^{2}$ Department of Pediatrics, Jang's Hospital, Seoul, Korea; ${ }^{3}$ Department of Pediatrics, Ulsan University College of Medicine, Seoul, Korea; ${ }^{4}$ Department of Pediatrics, Inje University Busan Paik Hospital, Inje University College of Medicine, Busan, Korea

The recent re-emergence of vitamin D deficiency (VDD) and rickets among breastfed infants without adequate sunlight exposure and vitamin D supplementation has been reported worldwide. Breastfed infants are particularly vulnerable to VDD because of the low vitamin D content of breast milk, restricted sunlight exposure, increased pollution, and limited natural dietary sources of vitamin D. The prevalence of VDD in breastfed infants differs vastly between studies and nations at $0.6 \%-91.1 \%$. The recommended intake of vitamin D for lactating mothers to optimize their overall vitamin D status and, consequently, of their breast milk is $200-2,000 \mathrm{IU} /$ day, indicating a lack of consensus. Some studies have suggested that maternal high-dose vitamin D supplementation (up to 6,400 IU/day) can be used as an alternate strategy to direct infant supplementation. However, concern persists about the safety of maternal high-dose vitamin D supplementation. Direct infant supplementation is the currently available option to support vitamin $\mathrm{D}$ status in breastfed infants. The recommended dose for vitamin $\mathrm{D}$ supplementation in breastfed infants according to various societies and organizations worldwide is $200-1,200$ IU/ day. Most international guidelines recommend that exclusively or partially breastfed infants be supplemented with $400 \mathrm{IU} /$ day of vitamin D during their first year of life. However, domestic studies on the status and guidelines for vitamin $\mathrm{D}$ in breastfed infants are insufficient. This review summarizes the prevalence of VDD in breastfed infants, vitamin D content of breast milk, and current guidelines for vitamin D supplementation of lactating mothers and infants to prevent VDD in breastfed infants.

Keywords: Vitamin D, Breastfeeding, Infant

\section{Key message}

- Exclusively breastfed infants are at risk of developing vitamin D deficiency associated with hypocalcemia, rickets, and various health outcomes.

- The prevalence of vitamin D deficiency in breastfed infants differs vastly between studies and nations at $0.6 \%-91.1 \%$.
- The vitamin D content of breast milk does not meet the requirements of exclusively breastfed infants.

- Most international guidelines recommend that breastfed infants be supplemented with $400 \mathrm{IU} /$ day of vitamin D during the first year of life.

- Vitamin D intake (milk+supplements) of $800 \mathrm{IU} /$ day can be considered in preterm infants along with biochemical monitoring.

\section{Introduction}

Vitamin D (calciferol), a fat-soluble steroid hormone, is important for regulating calcium homeostasis and bone health. ${ }^{1)}$ Moreover, the importance of vitamin $\mathrm{D}$ is emphasized as evidence supports an association between vitamin $\mathrm{D}$ and other health outcomes, such as immune function, respiratory diseases, allergy, olfactory function, cardiovascular diseases, obesity, insulin resistance, and cancer in pediatric and adolescent populations.-24)

Vitamin D exists in 2 forms: vitamin $\mathrm{D}_{3}$ (cholecalciferol), the mammalian form; and vitamin $\mathrm{D}_{2}$ (ergocalciferol), the fungal form. ${ }^{25)}$ In vivo, vitamin $\mathrm{D}_{3}$ can be synthesized in the epidermis through photochemical transformation of 7-dihydrocholesterol after exposure to ultraviolet radiation B (wavelength 280-320 $\mathrm{nm}$ ) energy. ${ }^{26-29)}$ Vitamin $\mathrm{D}_{2}$ and $\mathrm{D}_{3}$ can also be obtained through dietary intake; both follow the same metabolic pathways, and their actions are qualitatively similar. ${ }^{30)}$ Vitamin D is converted by 25 -hydroxylase to 25 -hydroxyvitamin $\mathrm{D}(25(\mathrm{OH}) \mathrm{D})$ in the liver and further metabolized to the biologically active form 1,25-dihydroxyvitamin $\mathrm{D}$ through $1 \alpha$-hydroxylation action in the kidney. Sunlight exposure often has a major influence on vitamin D status, accounting for over $90 \%$ of its level. ${ }^{31)}$ However, skin synthesis of vitamin $D$ is negatively influenced by a dark skin color, living in northern latitudes during winter, use of sunscreen with a high Sun Protection Factor, body covering, air pollution, and staying indoors for much of the day. ${ }^{32,33)}$ In comparison, the dietary intake of vitamin $\mathrm{D}$, in addition to fortified foods, has little impact on an individual's overall vitamin D status. ${ }^{33)}$

Corresponding author: Young Min Ahn, MD, PhD. Department of Pediatrics, Jang's Hospital, 411, Mangu-ro, Jungnang-gu, Seoul 02073, Korea 凶Email: ymahn964@naver.com, https://orcid.org/0000-0002-1697-8041

Received: 12 April 2021, Revised: 9 October 2021, Accepted: 15 November 2021

This is an open-access article distributed under the terms of the Creative Commons Attribution Non-Commercial License (http://creativecommons.org/licenses/by$\mathrm{nc} / 4.0 /$ ) which permits unrestricted non-commercial use, distribution, and reproduction in any medium, provided the original work is properly cited.

Copyright (c) 2022 by The Korean Pediatric Society 


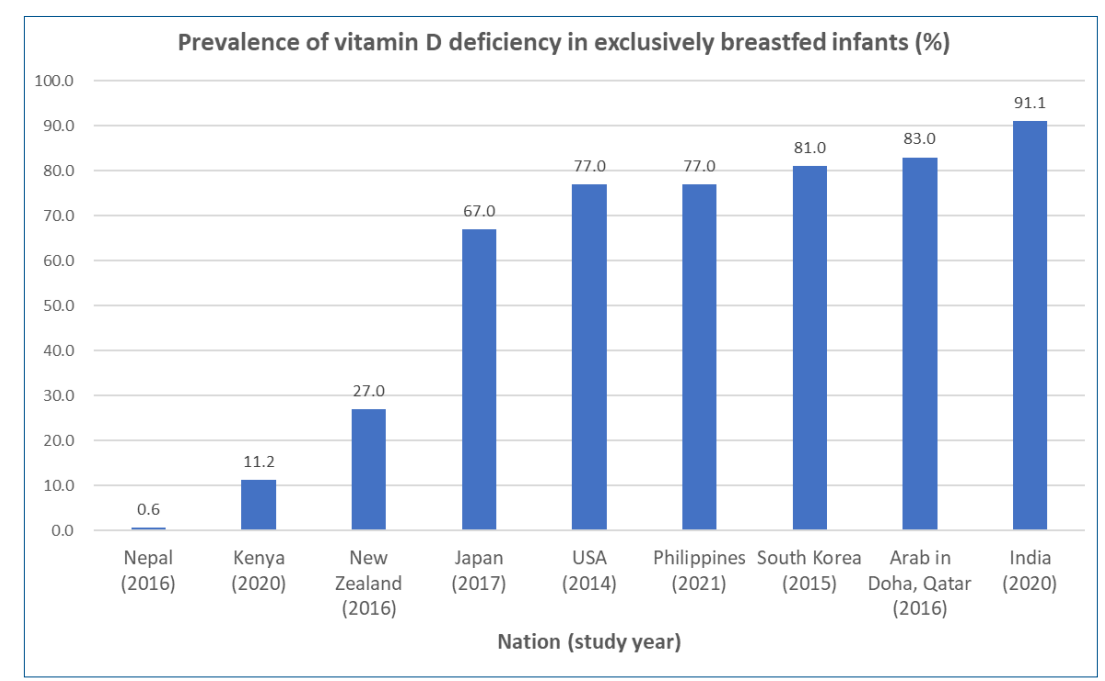

Graphical abstract

Table 1. Definitions of deficiency, insufficiency, and sufficiency of vitamin D according to clinical guidelines

\begin{tabular}{|c|c|c|c|c|}
\hline \multirow{2}{*}{ Society/organization } & \multirow{2}{*}{ Year } & \multicolumn{3}{|c|}{ 25-hydroxyviamin D (ng/mL $\left.L^{a)}\right)$} \\
\hline & & Deficiency & Insufficiency & Sufficiency \\
\hline Institute of Medicine ${ }^{25)}$ & 2011 & $<12$ & $12-19$ & $\geq 20$ \\
\hline The Endocrine Society ${ }^{45)}$ & 2011 & $<20$ & $21-29$ & $\geq 30$ \\
\hline European Society for Pediatric Gastroenterology Hepatology and Nutrition ${ }^{32)}$ & 2013 & $<20$ & - & $\geq 20$ \\
\hline Central Europe $e^{46)}$ & 2013 & $<20$ & $20-29$ & $\geq 30$ \\
\hline Society for Adolescent Health and Medicine ${ }^{47)}$ & 2013 & $<20$ & $20-29$ & $\geq 30$ \\
\hline American Academy of Pediatrics ${ }^{48)}$ & 2014 & $<20$ & - & $\geq 20$ \\
\hline European Food Safety Authority ${ }^{49)}$ & 2016 & - & - & $\geq 20$ \\
\hline Global Consensus for Rickets ${ }^{33)}$ & 2016 & $<12$ & $12-19$ & $\geq 20$ \\
\hline Japanese Society for Bone and Mineral Research, Japan Endocrine Society ${ }^{30)}$ & 2017 & $<20$ & $20-29$ & $\geq 30$ \\
\hline United Arab Emirates ${ }^{50)}$ & 2018 & $<20$ & $20-29$ & $\geq 30$ \\
\hline Korean Society of Pediatric Endocrinology ${ }^{54)}$ & 2019 & - & - & $\geq 20$ \\
\hline Australasia Paediatric Endocrine Group Bone and Mineral Working Group ${ }^{51)}$ & 2020 & $<12$ & $12-19$ & $\geq 20$ \\
\hline
\end{tabular}

a) $1 \mathrm{ng} / \mathrm{mL}=2.5 \mathrm{nmol} / \mathrm{L}$.

Breast milk is an important source of energy and nutrients for children until 2 years of age. To ensure optimal infant growth, development, and health, the World Health Organization (WHO) recommends exclusive breastfeeding for the first 6 months of life and the introduction of nutritionally adequate and safe complementary foods at 6 months together with continued breastfeeding up to 2 years of age or beyond. ${ }^{34)}$ However, human milk typically contains a small amount of vitamin D (approximately $\leq 25-50 \mathrm{IU} / \mathrm{L}),{ }^{1,25,35)}$ and the concentration is affected by the lactating mother's vitamin D status and season. ${ }^{36,37)}$ It is well known that a smaller amount of vitamin $\mathrm{D}$ is supplied to infants by lactating mothers with vitamin D deficiency (VDD). Therefore, exclusively breastfed infants are more likely to develop VDD, resulting in hypocalcemia and rickets if sunlight exposure is limited. ${ }^{30,38)}$ Vitamin D plays an important role in bone mineralization as well as the regulation of skeletal muscle function and the immune, nervous, and cardiovascular systems. ${ }^{39-42)}$ Therefore, it is very important to maintain an appropriate vitamin D level while continuing to breastfeed.

This review aims to examine the relationship between breast- feeding and vitamin D and review guidelines for vitamin D supplementation in lactating mothers and infants to prevent VDD in breastfed infants.

\section{Definition of deficiency, insufficiency, and sufficiency of vitamin D}

In the blood, 25(OH)D has a long half-life of 2-3 weeks and does not need to be strictly controlled to maintain homeostasis. Therefore, it is a good indicator of the level of vitamin D intake (cutaneous synthesis and dietary intake). ${ }^{36,43)}$ On the other hand, 1,25-dihydroxyvitamin D has a short half-life of 5-8 hours and is always maintained at a constant blood level in healthy people. ${ }^{44}$ The use of serum levels of 1,25-dihydroxyvitamin D is limited to monitoring certain conditions, such as acquired and inherited disorders of vitamin D and phosphate metabolism. ${ }^{45)}$ Guidelines for VDD/insufficiency/sufficiency defined by serum $25(\mathrm{OH}) \mathrm{D}$ concentrations have been published by many societies in many countries. $25,30,32,33,45-51)$ These guidelines are summarized in 
Table 1. According to published guidelines, a 25(OH)D level of $\leq 12-20 \mathrm{ng} / \mathrm{mL}$ is deficient, while a level of $\geq 20-30 \mathrm{ng} / \mathrm{mL}$ is sufficient.

In South Korea, there are no consensus guidelines regarding the definition of VDD/insufficiency or sufficiency based on 25(OH)D levels. In the 2020 Dietary Reference Intakes (DRIs) for Koreans, the optimal $25(\mathrm{OH}) \mathrm{D}$ level for bone health was determined to fall within the range that minimizes parathyroid hormone secretion and maximizes calcium absorption. ${ }^{36)}$ Based on previous studies, a 25(OH)D level of $20-30 \mathrm{ng} / \mathrm{mL}$ is considered the cut-off level that satisfies these conditions. ${ }^{52,53)}$ The clinical guidelines of the Korean Society of Pediatric Endocrinology do not recommend additional vitamin $\mathrm{D}$ supplementation when the $25(\mathrm{OH}) \mathrm{D}$ level is greater than $20 \mathrm{ng} / \mathrm{mL}^{54)}$ However, there are insufficient domestic data to support this suggestion.

\section{Vitamin D status of breastfed infants}

There are increasing reports of VDD among breastfed infants who do not receive vitamin D supplementation. ${ }^{55)}$ The vitamin D statuses of exclusively or nearly exclusively breastfed infants and their mothers are shown in Table 2. The prevalence of VDD differs greatly between studies and nations at $0.6 \%-91.1 \% .^{56-66)}$ Among these studies, 7 (63.6\%) reported a prevalence of VDD of $50 \%$ or higher in breastfed infants. A prevalence as high as 83\% was reported among 1-month-old infants in Qatar despite the region having abundant sunshine. ${ }^{61)}$ One study in India reported a prevalence of VDD of $91.1 \%$ among 6-month-old infants who were not on vitamin D supplementation. ${ }^{58)} \mathrm{VDD}$ in infants exclusively breastfed without vitamin D supplementation and sufficient sun exposure is a major cause of nutritional rickets, with a high prevalence in North America, South America, Europe, and parts of the Middle East. ${ }^{67)}$

In South Korea, a few studies have reported on the vitamin

Table 2. Vitamin D statuses of exclusively breastfed infants and their mothers

\begin{tabular}{|c|c|c|c|c|c|c|c|}
\hline First author, year & Country & $\begin{array}{l}\text { No. of } \\
\text { participants }\end{array}$ & $\begin{array}{l}\text { Age of } \\
\text { infants }\end{array}$ & $\begin{array}{l}25(\mathrm{OH}) \mathrm{D}(\mathrm{ng} / \mathrm{mL}) \\
\text { of mothers }\end{array}$ & $\begin{array}{l}25(\mathrm{OH}) \mathrm{D}(\mathrm{ng} / \mathrm{mL}) \\
\text { of infants }\end{array}$ & $\begin{array}{l}\text { Prevalence of VDD in } \\
\text { infants }\end{array}$ & Remark \\
\hline $\begin{array}{l}\text { Parian-de los } \\
\text { Angeles et al., } \\
2021^{56)}\end{array}$ & Philippines & 131 Infants & $<6 \mathrm{Mo}$ & - & - & $\begin{array}{l}\operatorname{VDD}(<15 \mathrm{ng} / \mathrm{mL}): 77 \% \\
\text { VDI (15-20 ng/mL): 10\% }\end{array}$ & \\
\hline $\begin{array}{l}\text { Said et al., } \\
2020^{57)}\end{array}$ & Kenya & 98 Infants & - & - & - & $\begin{array}{l}\operatorname{VDD}(<12 \mathrm{ng} / \mathrm{mL}): 11.2 \% \\
\operatorname{VDI}(12-20 \mathrm{ng} / \mathrm{mL}): 12.2 \%\end{array}$ & \\
\hline $\begin{array}{l}\text { Trivedi et al., } \\
2020^{58)}\end{array}$ & India & $56 \mathrm{M}-\mathrm{I}$ pairs & $6 \mathrm{Mo}$ & $6.29 \pm 4.11$ & $6.43 \pm 3.76$ & $\begin{array}{l}\operatorname{VDD}(<11 \mathrm{ng} / \mathrm{mL}): 91.1 \% \\
\operatorname{VDI}(11-19 \mathrm{ng} / \mathrm{mL}): 8.9 \%\end{array}$ & Control group \\
\hline $\begin{array}{l}\text { Terashita et al., } \\
2017^{59)}\end{array}$ & Japan & 9 Infants & $5 \mathrm{Mo}$ & - & $16.0 \pm 6.5$ & $\operatorname{VDD}(<20 \mathrm{ng} / \mathrm{mL}): 67 \%$ & $\begin{array}{l}\text { Vitamin D supple- } \\
\text { mentation (-) }\end{array}$ \\
\hline $\begin{array}{l}\text { Haugen et al., } \\
2016^{60)}\end{array}$ & Nepal & $500 \mathrm{M}-\mathrm{I}$ pairs & $1-12 \mathrm{Mo}$ & $21.2 \pm 8.1$ & $34.8 \pm 7.6$ & $\begin{array}{l}\operatorname{VDD}(<12 \mathrm{ng} / \mathrm{mL}): 0.6 \% \\
\operatorname{VDI}(12-19 \mathrm{ng} / \mathrm{mL}): 3.0 \%\end{array}$ & BM (full or partly) \\
\hline $\begin{array}{l}\text { Salameh et al., } \\
2016^{61)}\end{array}$ & $\begin{array}{l}\text { Arab in Doha, } \\
\text { Qatar }\end{array}$ & $60 \mathrm{M}-\mathrm{I}$ pairs & $1 \mathrm{Mo}$ & $13(10-18)$ & $8(5-13.5)$ & $\operatorname{VDD}(<20 \mathrm{ng} / \mathrm{mL}): 83 \%$ & \\
\hline $\begin{array}{l}\text { Wheeler et al., } \\
\text { 2016 }\end{array}$ & New Zealand & $30 \mathrm{M}-\mathrm{I}$ pairs & $5 \mathrm{Mo}$ & - & - & $\operatorname{VDD}(<20 \mathrm{ng} / \mathrm{mL}): 27 \%$ & $\begin{array}{l}71 \% \text { exc BM at } 5 \text { mo, } \\
\text { control group }\end{array}$ \\
\hline $\begin{array}{l}\text { Dawodu et al., } \\
2014^{63)}\end{array}$ & USA & $120 \mathrm{M}-\mathrm{I}$ pairs & $4 \mathrm{Wk}$ & $28.1 \pm 9.3$ & $16.4 \pm 6.5$ & $\operatorname{VDD}(<20 \mathrm{ng} / \mathrm{mL}): 77 \%$ & $\begin{array}{l}87.5 \% \text { exc BM at } 4 \\
\text { weeks }\end{array}$ \\
\hline $\begin{array}{l}\text { Wall et al., } \\
2013^{64)^{\prime}}\end{array}$ & New Zealand & 94 Infants & $2-3 \mathrm{Mo}$ & - & $21.2(5.6-40)$ & $\operatorname{VDD}(<11 \mathrm{ng} / \mathrm{mL}): 24 \%$ & \\
\hline $\begin{array}{l}\text { Jain et al., } \\
2011^{65)}\end{array}$ & India & $98 \mathrm{M}-\mathrm{I}$ pairs & $2.5-3.5 \mathrm{Mo}$ & $9.8(5.0-13.8)$ & $10.1(2.5-17.1)$ & $\begin{array}{l}\operatorname{VDD}(<15 \mathrm{ng} / \mathrm{mL}): 66.7 \% \\
\operatorname{VDI}(15-20 \mathrm{ng} / \mathrm{mL}): 19.8 \%\end{array}$ & $70.6 \%$ exc BM \\
\hline $\begin{array}{l}\text { Agarwal et al., } \\
2010^{66)}\end{array}$ & India & $97 \mathrm{M}-\mathrm{I}$ pairs & $10 \mathrm{Wk}$ & $9.34 \pm 6.18$ & $11.55 \pm 7.27$ & $\operatorname{VDD}(<11 \mathrm{ng} / \mathrm{mL}): 55.67 \%$ & \\
\hline $\begin{array}{l}\text { Kang et al., } \\
2015^{68)}\end{array}$ & South Korea & $70 \mathrm{M}-\mathrm{I}$ pairs & 4-24 Mo & $12.4 \pm 4.4$ & $11.4 \pm 8.6$ & $\operatorname{VDD}(\leq 20 \mathrm{ng} / \mathrm{mL}): 81 \%$ & \\
\hline $\begin{array}{l}\text { Choi et al., } \\
2013^{69)}\end{array}$ & South Korea & 52 Infants & $1-6 \mathrm{Mo}$ & - & 9.35 & $\operatorname{VDD}(<20$ ng/mL): 90.4\% & $\begin{array}{l}\text { Feeding } \mathrm{BM}>80 \% \text { of } \\
\text { total feeding vol- } \\
\text { ume/day }\end{array}$ \\
\hline $\begin{array}{l}\text { Kim et al., } \\
2010^{70)}\end{array}$ & South Korea & $28 \mathrm{M}-\mathrm{I}$ pairs & 0-12 Mo & $24.5 \pm 12.5$ & $\begin{array}{l}0 \rightarrow 6 \rightarrow 12 \mathrm{mo:} \\
18.0 \pm 10.3 \rightarrow \\
22.5 \pm 9.24 \rightarrow \\
33.2 \pm 7.89\end{array}$ & $\begin{array}{l}0 \rightarrow 6 \rightarrow 12 \mathrm{mo}: \\
\text { VDD }(<11 \mathrm{ng} / \mathrm{mL}) \\
26.9 \% \rightarrow 10.7 \% \rightarrow 0 \% \\
\text { VDI }(11-30 \mathrm{ng} / \mathrm{mL}) \\
61.5 \% \rightarrow 67.9 \% \rightarrow 50.0 \%\end{array}$ & $\begin{array}{l}\text { Exc BM without sup- } \\
\text { plementation }\end{array}$ \\
\hline $\begin{array}{l}\text { Park et al., } \\
1998^{711}\end{array}$ & South Korea & 18 Infants & $2-5 \mathrm{Mo}$ & - & $16.0 \pm 11.3$ & VDD (<11 ng/mL) 44\% & \\
\hline
\end{tabular}


D status of breastfed infants (Table 2). ${ }^{68-71)}$ The prevalence of VDD varied among the studies according to definitions of VDD. In studies conducted before 2010, VDD was defined as a $25(\mathrm{OH}) \mathrm{D}$ level of $<11 \mathrm{ng} / \mathrm{mL}$. Park et al. ${ }^{71)}$ found that the prevalence of VDD was $44 \%$ among breastfed infants, higher than the $6 \%$ among formula-fed infants. Kim et al. ${ }^{70}$ reported that concentrations of vitamin D were measured at 0,6 , and 12 months. Among breastfed infants without supplementation, the prevalence of VDD gradually decreased from birth (26.9\%) to 12 months of age $(0 \%)$. In studies published after 2013 , however, the prevalence of VDD increased up to $81 \%-90.4 \% .^{68,69)}$ This increase may have been caused by changes in the definition of VDD as $25(\mathrm{OH}) \mathrm{D}$ level $<20 \mathrm{ng} / \mathrm{mL}$, although the possibility of an increase in actual VDD infants cannot be ruled out.

Based on previous studies, the prevalence of VDD is high in exclusively breastfed infants, even in South Korea. Further largescale domestic studies are necessary to evaluate the exact vitamin D status of breastfed infants.

\section{Vitamin D content of breast milk}

According to studies conducted in the 1980s, breast milk contains both vitamin D and 25(OH)D. ${ }^{72,73)}$ Vitamin D and $25(\mathrm{OH}) \mathrm{D}$, known for their antirachitic activity (ARA; expressed in $\mathrm{IU} / \mathrm{L}$ ), are responsible for $\geq 90 \%$ of the total vitamin D activity in breast milk. ${ }^{73)}$ The dihydroxylated metabolites did not contribute significantly to the total vitamin $\mathrm{D}$ activity. ARA is calculated as $1 \mathrm{IU} / \mathrm{L}=25 \mathrm{pg} / \mathrm{mL}$ vitamin $\mathrm{D}=5 \mathrm{pg} / \mathrm{mL}$ vitamin $25(\mathrm{OH}) \mathrm{D} .{ }^{74)}$ A very small amount (approximately $1 \%$ ) of the $25(\mathrm{OH}) \mathrm{D}$ circulating in the maternal blood crosses into the breast milk $;^{75)}$ in contrast, $20 \%-30 \%$ of the circulating vitamin $\mathrm{D}$ is expressed in the breast milk. ${ }^{76)}$ However, vitamin D is rapidly converted to $25(\mathrm{OH}) \mathrm{D}$; therefore, the concentration of vitamin $\mathrm{D}$ circulating in the maternal blood decreases rapidly unless recent sunlight exposure and adequate vitamin D supplementation are provided.

Previous studies reported that the ARA levels in the breast milk of Western mothers were $14-170$ IU/L (Table 3). ${ }^{72-74,77-79)}$ However, there is a dearth of studies on vitamin $\mathrm{D}$ content of the breast milk of Asian mothers. A recent study compared vitamin

Table 3. Antirachitic activity of breast milk in examined studies

\begin{tabular}{|c|c|c|c|}
\hline Study & Year & Country & ARA of vitamin D and $25(\mathrm{OH}) \mathrm{D}$ in breast milk* \\
\hline Hollis et al., ${ }^{72)}$ & 1981 & USA & $\begin{array}{l}\text { Vitamin D: } 1.56 \pm 0.36 \mathrm{IU} / \mathrm{L} \\
25(\mathrm{OH}) \mathrm{D}: 62.2 \pm 6.2 \mathrm{U} / \mathrm{L}\end{array}$ \\
\hline Reeve et al., ${ }^{73)}$ & 1982 & USA & $\begin{array}{l}\text { Vitamin D2 and D3: 14-16 IU/L } \\
\text { 25(OH)D: } 33 \mathrm{IU} / \mathrm{L}\end{array}$ \\
\hline Ala-Houhala et al., ${ }^{77)}$ & 1988 & Finland & 124 (19-332) IU/L in summer, 14 (8-30) IU/L in winter \\
\hline Sakurai et al., ${ }^{81)}$ & 2005 & Japan & Vitamin D3: $3.2 \pm 4.3 \mathrm{IU} / \mathrm{L}$ \\
\hline Kamao et al., ${ }^{82)}$ & 2007 & Japan & $\begin{array}{l}\text { Vitamin } \mathrm{D}_{3}: 3.5 \mathrm{IU} / \mathrm{L} \\
25(\mathrm{OH}) \mathrm{D}_{3}: 16.2 \mathrm{IU} / \mathrm{L}\end{array}$ \\
\hline Jan Mohamed et al.. ${ }^{83)}$ & 2014 & Malaysia & 25(OH)D: $80.8-100.8 \mathrm{IU} / \mathrm{L}$ \\
\hline við Streym et al., ${ }^{78)}$ & 2016 & Denmark & $\begin{array}{l}\text { Vitamin D } \\
\text { Foremilk in winter: } 1.6(1.6-6.4) \mathrm{IU} / \mathrm{L} \\
\text { Foremilk in summer: } 6.4(1.6-20.8) \mathrm{IU} / \mathrm{L} \\
\text { Hindmilk in winter: } 4.8(1.6-14.4) \mathrm{IU} / \mathrm{L} \\
\text { Hindmilk in summer: } 14.4(4.8-48) \mathrm{IU} / \mathrm{L} \\
\text { 25(OH)D } \\
\text { Foremilk in winter: } 64 \text { (40-88) IU/L } \\
\text { Foremilk in summer: } 72(56-120) \mathrm{IU} / \mathrm{L} \\
\text { Hindmilk in winter: } 96 \text { (64-128) IU/L } \\
\text { Hindmilk in summer: } 128(88-176) \mathrm{IU} / \mathrm{L}\end{array}$ \\
\hline Stoutjesdijk et al., ${ }^{74)}$ & 2017 & $\begin{array}{l}\text { Netherland } \\
\text { Curaçao } \\
\text { Vietnam } \\
\\
\text { Malaysia } \\
\text { Tanzania }\end{array}$ & $\begin{array}{l}46 \text { (3-51) IU/L } \\
31 \text { (5-113) IU/L } \\
\text { Halong Bay } 58(23-110) \text { IU/L } \\
\text { Phu Tho } 28(1-62) \text { IU/L } \\
\text { Tien Giang } 63 \text { (26-247) IU/L } \\
\text { Ho-Chi-Minh-City 49 (24-116) IU/L } \\
\text { Hanoi } 37(11-118) \text { IU/L } \\
\text { Kuala Lumpur 14 (1-46) IU/L } \\
\text { Ukerewe } 77(12-232) \text { IU/L } \\
\text { Maasai } 88 \text { (43-189) IU/L }\end{array}$ \\
\hline Oberson et al., ${ }^{79)}$ & 2020 & USA & $33.4-172.3 \mathrm{IU} / \mathrm{L}$ \\
\hline Tsugawa et al., ${ }^{37)}$ & 2021 & Japan & $31.3 \pm 30.3 \mathrm{IU} / \mathrm{L}$ in $1989,25.5 \pm 12.0 \mathrm{IU} / \mathrm{L}$ in $2016-2017$ \\
\hline
\end{tabular}

Values are presented as mean \pm standard deviations or median (range).

25(OH)D, 25-hydroxyvitamin D.

*ARA (calculated antirachitic activity)=biological activity of $25(\mathrm{OH}) \mathrm{D}+$ biological activity of vitamin D. Biological activity of vitamin $\mathrm{D}, 1 \mathrm{lU} / \mathrm{L}=25 \mathrm{pg} / \mathrm{mL}$; biological activity of $25(\mathrm{OH}) \mathrm{D}, 1 \mathrm{IU} / \mathrm{L}=5 \mathrm{pg} / \mathrm{mL}$. 
concentrations of the breast milk of women from South Korea, China, Pakistan, and Vietnam. ${ }^{80)}$ However, the concentrations of vitamin $\mathrm{D}_{2}$ and $\mathrm{D}_{3}$ in the breast milk samples from all 4 countries were lower than the limit of detection of $\mathrm{D}_{2}=0.5 \mathrm{ng} /$ $\mathrm{mL}$ and $\mathrm{D}_{3}=1 \mathrm{ng} / \mathrm{mL}$. Three studies in Japan evaluated vitamin D concentrations of breast milk. One study compared the vitamin D concentrations of breast milk between 1989 and 2016-2017.37) The mean total ARA of breast milk from 1989 to 2016-2017 decreased from 31.3 IU/L to $25.5 \mathrm{IU} / \mathrm{L}$, respectively. In the other 2 studies from Japan, the mean ARA of vitamin $\mathrm{D}_{3}$ and $25(\mathrm{OH}) \mathrm{D}_{3}$ were $3.2-3.5 \mathrm{IU} / \mathrm{L}$ and $16.2 \mathrm{IU} / \mathrm{L}$, respectively. ${ }^{81,82)}$ The study conducted in Malaysia reported higher 25(OH)D levels (80.8-100.8 IU/L) than those reported in Japanese studies. ${ }^{83)}$

On combining studies from different countries, the levels of vitamin $\mathrm{D}$ of breast milk did not meet the vitamin $\mathrm{D}$ requirements of exclusively breastfed infants despite the mothers being exposed to abundant lifetime sunlight. ${ }^{74)}$

\section{Effects of vitamin $D$ supplementation of lactating mothers on vitamin D status and bone health of breastfed infants}

The vitamin D content of breast milk is related to the vitamin D status of lactating mothers. ${ }^{74,84-87)}$ Lactating mothers with VDD would have a reduced amount of vitamin $\mathrm{D}$ in their breast milk, resulting in VDD in breastfed infants. ${ }^{88)}$ Therefore, there have been some efforts to supply adequate vitamin D to the nursing infants through maternal vitamin D supplementation.

The dietary recommendations of vitamin D for lactating mothers differ among advisory bodies, ranging from 200 to 2,000 IU/day. ${ }^{25,33,45,46,51,89,90)}$ The Institute of Medicine suggested $600 \mathrm{IU} /$ day for lactating mothers, ${ }^{25)}$ whereas the Endocrine Society suggested 1,500-2,000 IU/day. ${ }^{45)}$ Consensus is lacking on the recommended intake of vitamin D for lactating mothers, and the supplemental vitamin D dose that optimizes the vitamin D status of mothers and breast milk is unclear. In South Korea, the 2020 DRIs for Koreans recommended vitamin D supplementation of $400 \mathrm{IU} /$ day for lactating mothers. ${ }^{36)}$ In previous studies, however, the breast milk of a mother receiving a vitamin $\mathrm{D}$ dose of $400 \mathrm{IU} /$ day contains very low vitamin D concentrations of approximately 25-80 IU/L, which is far below the recommended daily vitamin D intake for infants. ${ }^{84,87,91,92)}$ The WHO panel acknowledged that supplementation during lactation to improve the vitamin $\mathrm{D}$ content of breast milk may require a maternal intake much higher than $600 \mathrm{IU} /$ day. ${ }^{91,93-95)}$

A recent meta-analysis evaluated the effects of maternal vitamin $\mathrm{D}$ supplementation on the vitamin $\mathrm{D}$ status and bone health of term breastfed infants. ${ }^{96}$ It included 5 randomized controlled trials (RCTs) comparing supplementation with placebo or no treatment. ${ }^{58,62,97-99)}$ These studies reported a mean vitamin D level of 266 for vitamin D-supplemented mothers and 246 for controls, and the converted daily doses of vitamin
D were 1,785-4,000 IU/day, higher than the current recommended dose. The results showed that high-dose vitamin D supplementation of lactating mothers may increase the $25(\mathrm{OH})$ $\mathrm{D}$ level (mean difference, $24.62 \mathrm{nmol} / \mathrm{L} ; 95 \%$ confidence interval [CI], 21.59-27). ${ }^{60)}$ in their children and reduce the incidence of vitamin D insufficiency (risk ratio [RR], 0.47; 95\% CI, 0.39-0.57), VDD (RR, 0.15; 95\% CI, 0.09-0.24), and biochemical rickets (RR, 0.06; 95\% CI, 0.01-0.44) in breastfed infants compared with placebo or no treatment. ${ }^{96)}$ However, there was insufficient evidence of the effects on bone mineral content and radiological rickets.

Studies have focused on methods of maternal supplementation to achieve vitamin D-replete milk to avoid direct infant supplementation. Wagner et al. ${ }^{87)}$ found that the supplementation of lactating women with $6,400 \mathrm{IU} /$ day of vitamin D for 6 months significantly improved maternal vitamin D status and increased the ARA of the breast milk from $82 \mathrm{IU} / \mathrm{L}$ to 873 IU/L. The mean plasma 25(OH)D level in exclusively breastfed infants was $46 \mathrm{ng} / \mathrm{mL}$, similar to that of the unsupplemented mothers' infants receiving $300 \mathrm{IU} /$ day of vitamin D. Maternal and infant urinary calcium-to-creatinine ratios remained within the reference range for both groups. This was confirmed by a large RCT in which maternal intake of 6,400 IU/day resulted in a supply of breast milk with adequate vitamin D to satisfy their nursing infants' requirements. ${ }^{100)}$ Maternal high-dose supplementation $(6,400 \mathrm{IU} /$ day) resulted in similar $25(\mathrm{OH}) \mathrm{D}$ levels in infants supplemented with $400 \mathrm{IU} /$ day. Another RCT recently evaluated the effects of intermittent mega-dose of vitamin D on lactating mothers in India. ${ }^{58)}$ In this study, mothers received either vitamin $\mathrm{D}_{3} 60,000 \mathrm{IU}$ at 24-48 hours postpartum and at 6,10 , and 14 weeks amounting to $240,000 \mathrm{IU}$ of vitamin $\mathrm{D}_{3}$ or placebo. They reported that the intervention groups had higher serum $25(\mathrm{OH}) \mathrm{D}$ concentrations in exclusively breastfed infants and a $94.6 \%$ and $48.1 \%$ reduction in the risk of VDD and vitamin D insufficiency, respectively, at 6 months of age. Neither the mother nor the infant experienced adverse effects.

However, concern persists about maternal high-dose vitamin D supplementation despite the lack of adverse effects. These high vitamin $\mathrm{D}$ doses are above the recommended upper limit of 4,000 IU/day for lactating mothers. ${ }^{25,101)}$ The global consensus recommendations highlight that lactating women should not consume high amounts of vitamin D to supplement their infants. ${ }^{33)}$ The clinical protocol of the Academy of Breastfeeding Medicine recommends maternal high-dose supplementation only if direct infant supplementation is contraindicated. ${ }^{102)}$

Thus far, the final consensus is that supplementing both mothers and infants with vitamin $\mathrm{D}$, rather than supplementing mothers alone with high-dose vitamin $\mathrm{D}$, ensures a healthy vitamin D status in their infants. 


\section{Guidelines for vitamin D supplementation in breastfed infants}

Direct infant supplementation is the currently available option to improve vitamin $\mathrm{D}$ levels. This supplement should be vitamin $\mathrm{D}_{3}$ because of its superior absorption compared to vitamin $\mathrm{D}_{2 .}{ }^{102)}$ The recommended dose for vitamin $\mathrm{D}$ supplementation in breastfed infants is available from various societies and organizations worldwide and differs among them (Table 4). The WHO provides general recommendations for specific vulnerable groups. The WHO recommends $200 \mathrm{IU} /$ day of vitamin D for infants aged $<1$ year. ${ }^{89)}$

In 2003, the American Academy of Pediatrics (AAP) recom. mended that all infants, including those who are exclusively breastfed, should have a minimum intake of $200 \mathrm{IU} /$ day of vitamin $\mathrm{D}$ beginning in the first 2 months of life. ${ }^{35)}$ In 2008, the $\mathrm{AAP}$, with the primary intention of preventing rickets considering new evidence from clinical trials, increased the recommended intake of vitamin D for infants aged $<1$ year from $200 \mathrm{IU} /$ day to $400 \mathrm{IU} /$ day beginning soon after birth. ${ }^{103)}$ The guidelines stated that exclusively or partially breastfed infants should be supplemented with $400 \mathrm{IU} /$ day of vitamin D. For nonbreastfed infants ingesting $<1,000 \mathrm{~mL} /$ day of vitamin $\mathrm{D}$-fortified formula or milk, the AAP recommended vitamin D supplementation of $400 \mathrm{IU} /$ day as well. ${ }^{103)}$ In 2011, the Institute of Medicine (now known as the National Academy of Medicine) agreed with this recommendation, ${ }^{25)}$ and the AAP, through an endorsement of the Institute of Medicine report in 2012 ${ }^{104)}$ and a clinical report in 2014, ${ }^{48)}$ re-emphasized its original 2008 recommendation.

Most European countries as well as the Unites States recom. mend vitamin D supplementation with at least $400 \mathrm{IU} /$ day for infants during the first year of life. ${ }^{46}$ The European Society for Pediatric Gastroenterology, Hepatology and Nutrition (ESPGHAN) also stated that all infants should receive oral supplementation of $400 \mathrm{IU} /$ day of vitamin D. However, the Committee on Nutrition of the French Society of Pediatrics recommended higher doses of vitamin $\left.\mathrm{D} .{ }^{105}\right)$ The recommendations were as follows: 1,000-1,200 IU/day for breastfed infants, 600-800 IU/day for children $\leq 18$ months of age receiving milk supplemented with vitamin D; and 1,000-1,200 IU for children less than 18 months of age receiving milk not supplemented with vitamin D. Closely followed supplementation of breastfed infants with 1,000 IU/day of vitamin $\mathrm{D}$ has helped prevent the resurgence of rickets in France. ${ }^{105)}$

In Japan, the DRIs were revised in 2020. ${ }^{106}$ ) The Japanese DRIs are influenced by tentative dietary goals to prevent lifestylerelated diseases. Adequate intake (AI) in infants was defined as the vitamin D concentration in the breast milk multiplied by the typical intake of $0.78 \mathrm{~L} /$ day. However, considering the evidence of the re-emergence of VDD rickets and low content of vitamin D of breast milk, ${ }^{107)}$ the $\mathrm{AI}$ was set at $200 \mathrm{IU} /$ day for both male and female infants aged $<1$ year. ${ }^{106}$

In South Korea, there are no national guidelines regarding vitamin D intake in breastfed infants. The 2020 DRIs for Koreans recommend a dose of $200 \mathrm{IU} /$ day of vitamin D as the AI for infants, similar to the 2015 DRIs for Koreans. ${ }^{36}$ ) The Korean Society of Pediatric Endocrinology suggested 400-600 IU/day of vitamin D supplementation for infants, children, and adolescents ${ }^{54}$ based on the guidelines of the Institute of Medicine and the AAP.25,48) It is necessary to develop Korean guidelines for vitamin $\mathrm{D}$ supplementation based on evidence from domestic studies on vitamin D levels in the blood considering sunlight exposure and food intake.

Most international guidelines recommend $400 \mathrm{IU} /$ day of vitamin $\mathrm{D}$ for infants aged $<1$ year after birth. A recent metaanalysis showed that vitamin D supplementation of $400 \mathrm{IU} /$ day may increase the 25(OH)D level (mean difference, 22.63 $\mathrm{nmol} / \mathrm{L} ; 95 \% \mathrm{CI}, 17.05-28.21$ ) and may reduce the incidence

Table 4. Dietary recommended intakes (IU) of vitamin D for infants and children

\begin{tabular}{|c|c|c|c|}
\hline Society/organization & Age $0-1$ yr & Age $1-3 \mathrm{yr}$ & Age $4-10 \mathrm{yr}$ \\
\hline Worldwide (WHO/FAO, 2014) $)^{135)}$ & 200 & 200 & 200 \\
\hline Global consensus, 2016 33) & 400 & 600 & 600 \\
\hline USA (Endocrine Society, 2011) ${ }^{45)}$ & $400-1,000$ & $600-1,000$ & $600-1,000$ \\
\hline USA (IOM, 2011) $)^{25)}$ & 400 & 600 & 600 \\
\hline USA (AAP, 2014) & 400 & 600 & 600 \\
\hline France (French Society of Pediatrics, 2012) ${ }^{105)}$ & $1,000-1,200$ & $\begin{array}{l}<18 \text { mo: fortified milk } 600-800 \text {, not fortified } \\
\text { milk 1,000-1,200 } \\
\geq 18 \text { mo: } 2 \times 80,000-100,000 \text { ( } 1 \text { Nov and } 1 \\
\text { Feb) }\end{array}$ & $\begin{array}{l}<5 \text { yr: } 2 \times 80,000-100,000 \text { (1 Nov and } \\
1 \text { Feb) } \\
\geq 5 \text { yr: (-) }\end{array}$ \\
\hline $\begin{array}{l}\text { Central Europe (Polish Scientific Committee on } \\
\text { Vitamin D, 2013) }\end{array}$ & $400-600$ & $600-1,000$ & $600-1000$ \\
\hline Europe (ESPGHAN, 2013) ${ }^{32)}$ & 400 & - & - \\
\hline Japan (DRIs, 2020) ${ }^{106)}$ & 200 & $\begin{array}{l}\text { Male: } 120-140 \\
\text { Female: } 140-160\end{array}$ & $\begin{array}{c}\text { Male: } 140-200 \\
\text { Female: } 160-240\end{array}$ \\
\hline Korea (KSPE, 2019) ${ }^{54)}$ & 400 & 600 & 600 \\
\hline Korea (DRIs by MOHW and KNS, 2020) & 200 & 200 & 200 \\
\hline
\end{tabular}


of vitamin D insufficiency [25(OH)D] (RR, 0.57; 95\% CI, 0.41-0.80) compared with placebo or no treatment among term breastfed infants. $\left.{ }^{96}\right)$ However, there is insufficient evidence of the effect of supplementation on VDD and bone health.

\section{Vitamin D supplementation for preterm infants}

Preterm infants are at a high risk of VDD for several reasons: (1) decreased transplacental transfer, (2) minimal vitamin D formation mediated by ultraviolet $\mathrm{B}$ due to prolonged hospitalization, (3) minimal fat mass in which vitamin D and its metabolites are stored, and (4) a relatively high vitamin D requirement. ${ }^{108-110)} \mathrm{A}$ lack of vitamin $\mathrm{D}$ supplementation in the early postnatal period is a risk factor for metabolic bone disease in preterm infants. ${ }^{111,112)}$ Therefore, supplementation with an optimal dose of vitamin $\mathrm{D}$ is very important for preterm infants.

The AAP recommends vitamin D intake of 200-400 IU/ day for very low birth weight infants (birth weight $<1,500 \mathrm{~g}$ ) (Table 5). ${ }^{108)}$ For preterm infants with a birth weight $\geq 1,500$ $\mathrm{g}$, the recommended intake of vitamin $\mathrm{D}$ was $400 \mathrm{IU} /$ day with a maximum upper level of 1,000 IU/day, similar to the recommended intake for full-term infants. Meanwhile, the ESPGHAN guidelines generally suggest a daily vitamin D

Table 5. Summary of recommendations and randomized controlled trials of different doses of vitamin D for preterm infants

\begin{tabular}{|c|c|c|c|}
\hline Study & Population & Recommendations & \\
\hline AAP, 2013 & $\begin{array}{l}<1,500 \mathrm{~g} \\
\geq 1,500 \mathrm{~g}\end{array}$ & $\begin{array}{l}\text { 200-400 IU/day } \\
400-1,000 \text { IU/day }\end{array}$ & \\
\hline ESPGHAN, 2010 ${ }^{110)}$ & $<1,800 \mathrm{~g}$ & $800-1,000$ IU/day & \\
\hline ESPGHAN, 2019 ${ }^{113)}$ & 32-36 weeks & At least $400 \mathrm{IU} /$ day & \\
\hline Study & Population & $\begin{array}{l}\text { No. of participants } \\
\text { according to the groups }\end{array}$ & Findings \\
\hline $\begin{array}{l}\text { Natarajan et al., } \\
2014^{114)}\end{array}$ & 28-34 Weeks & $\begin{array}{c}800 I U(n=48) \text { vs. } \\
400 I U(n=48)\end{array}$ & $\begin{array}{l}800 \text { IU (vs. } 400 \text { IU) } \\
- \text { VDD at } 40 \text { weeks' PMA } \downarrow(38.1 \% \text { vs. 66.7\%) } \\
\text { - VDD at } 3 \text { month's CA } \downarrow(12.5 \% \text { vs. 35\%) } \\
\text { - Bone mineral content, bone mineral density } \rightarrow \\
\text { - Vitamin D excess ( } 100-150 \mathrm{ng} / \mathrm{mL}): 1(2.4 \%) \text { in the } 800 \mathrm{IU} \text { group }\end{array}$ \\
\hline Fort et al., 2016 & 23-27 Weeks & $\begin{array}{l}800 \mathrm{IU}(n=30) \text { vs. } \\
200 \mathrm{IU}(n=34) \text { vs. } \\
\text { placebo }(n=36)\end{array}$ & $\begin{array}{l}800 \text { IU (vs. } 200 \text { IU vs. placebo) } \\
-25(O H) D \text { at day } 28 \uparrow(84.5 \mathrm{ng} / \mathrm{mL} \text { vs. } 39 \mathrm{ng} / \mathrm{mL} \text { vs. } 22 \mathrm{ng} / \mathrm{mL}) \\
\text { - VDD (0\% vs. } 16 \% \text { vs. } 41 \%, P=0.2) \\
\text { - days alive, respiratory outcomes } \rightarrow\end{array}$ \\
\hline $\begin{array}{l}\text { Mathur et al., } \\
2016^{120)}\end{array}$ & $<1,500 \mathrm{~g}$ & $\begin{array}{l}1,000 \mathrm{IU}(\mathrm{n}=25) \text { vs. } \\
400 \mathrm{IU}(\mathrm{n}=25)\end{array}$ & $\begin{array}{l}\text { 1,000 IU (vs. } 400 \text { IU) } \\
\text { - Serum } 25(\mathrm{OH}) \mathrm{D} \text { after } 6 \text { weeks of supplementation } \uparrow(50.9 \mathrm{ng} / \mathrm{mL} \text { vs. } 29.7 \mathrm{ng} / \mathrm{mL}) \\
\text { - VDD } \downarrow(0 \% \text { vs. } 20 \%) \\
\text { - Calcium } \uparrow, \text { ALP } \downarrow \text {, parathyroid hormone } \downarrow \\
\text { - Skeletal hypomineralization } \downarrow \text {, growth } \uparrow\end{array}$ \\
\hline $\begin{array}{l}\text { Tergestina et al., } \\
2016^{116)}\end{array}$ & 27-34 Weeks & $\begin{array}{l}1,000 \mathrm{IU}(\mathrm{n}=60) \text { vs. } \\
400 \mathrm{IU}(\mathrm{n}=60)\end{array}$ & $\begin{array}{l}1,000 \text { IU (vs } 400 \text { IU) } \\
\text { - VDD at } 40 \text { weeks' PMA } \downarrow(2 \% \text { vs } 64.6 \%) \\
\text { - 25(OH)D at } 40 \text { weeks' PMA } \uparrow(47.47 \mathrm{ng} / \mathrm{mL} \text { vs. } 17.48 \mathrm{ng} / \mathrm{mL}) \\
\text { - Parathyroid hormone } \downarrow, \text { calcium } \rightarrow, \text { phosphorus } \rightarrow, \text { ALP } \rightarrow \\
\text { - Vitamin } D \text { excess }(>70 \mathrm{ng} / \mathrm{mL}): 9.8 \% \text { of } 1,000 \text { IU group, but not associated with } \\
\text { clinical or biochemical evidence of toxicity } \\
\text { - Hypercalcemia } \rightarrow \text {, elevated urine calcium/creatinine } \rightarrow\end{array}$ \\
\hline $\begin{array}{l}\text { Anderson-Berry et } \\
\text { al., } 2017^{117)}\end{array}$ & 24-32 Weeks & $\begin{array}{c}800 \mathrm{IU}(n=16) \text { vs. } \\
400 \mathrm{IU}(\mathrm{n}=16)\end{array}$ & $\begin{array}{l}800 \mathrm{IU}(\mathrm{vs} 400 \mathrm{IU}) \\
-25(\mathrm{OH}) \mathrm{D} \text { at } 4 \text { weeks } \uparrow(42.12 \mathrm{ng} / \mathrm{mL} \text { vs. } 33.84 \mathrm{ng} / \mathrm{mL}) \\
\text { - DEXA bone density measurements }<10 \mathrm{p} \downarrow(16 \% \text { vs 56\%) }\end{array}$ \\
\hline $\begin{array}{l}\text { Bozkurt et al., } \\
2017^{118)}\end{array}$ & 24-32 Weeks & $\begin{array}{l}1,000 \mathrm{IU}(\mathrm{n}=40) \text { vs. } \\
800 \mathrm{IU}(\mathrm{n}=41) \text { vs. } \\
400 \mathrm{IU}(\mathrm{n}=40)\end{array}$ & $\begin{array}{l}1,000 \mathrm{IU} \text { (vs. } 800 \mathrm{IU} \text { vs. } 400 \mathrm{IU}) \\
\text { - 25(OH)D at } 36 \text { weeks' PMA } \uparrow(43 \mathrm{ng} / \mathrm{mL} \text { vs. } 40 \mathrm{ng} / \mathrm{mL} \text { vs. } 29.4 \mathrm{ng} / \mathrm{mL}) \\
\text { - VDD at } 36 \text { weeks' PMA compared to } 400 \mathrm{IU} \downarrow(2.5 \% \text { vs. } 22.5 \%) \\
\text { - Vitamin D insufficiency at } 36 \text { weeks' PMA compared to } 400 \mathrm{IU} \downarrow(12 \% \text { vs. } 23 \%) \\
\text { - Calcium, phosphorus, ALP, parathyroid hormone } \rightarrow \\
\text { - Urine calcium/creatinine } \rightarrow\end{array}$ \\
\hline $\begin{array}{l}\text { Abdel-Hady et al., } \\
2019^{119)}\end{array}$ & $\begin{array}{l}\text { 28-36 Weeks } \\
\text { with LOS }\end{array}$ & $\begin{array}{c}800 I U(n=25) \text { vs. } \\
400 I U(n=25)\end{array}$ & $\begin{array}{l}800 \text { IU (vs. } 400 \text { IU) } \\
- \text { VDD at } 40 \text { weeks' PMA } \rightarrow \\
\text { - 25(OH)D at } 40 \text { weeks' PMA } \uparrow(67.4 \mathrm{ng} / \mathrm{mL} \text { vs. } 54.8 \mathrm{ng} / \mathrm{mL}) \\
\text { - IL-6, TNF-a, growth, duration of oxygen and respiratory support, duration of } \\
\text { antimicrobial use, length of hospital stay, mortality } \rightarrow \\
\text { - Vitamin D toxicity (-) }\end{array}$ \\
\hline
\end{tabular}

AAP, American Academy of Pediatrics; ESPGHAN, European Society for Pediatric Gastroenterology Hepatology and Nutrition; VDD, vitamin D deficiency; PMA, postmenstrual age; CA, corrected age; 25(OH)D, 25-hydroxyvitamin D; ALP, alkaline phosphatase; DEXA, dual-energy x-ray absorptiometry; IL, interleukin; LOS, late-onset sepsis; TNF, tumor necrosis factor.

$\uparrow$, significantly higher in the high-dose group; $\downarrow$, significantly lower in the high-dose group; $\rightarrow$, no significant differences between groups. 
intake of 800-1,000 IU/day for preterm infants up to a weight of approximately $1,800 \mathrm{~g}$ and at least $400 \mathrm{IU} /$ day for late and moderately preterm infants. ${ }^{110,113)}$

Several RCTs published after 2011 compared the efficacy of low-dose (200-400 IU/day) and high-dose (800-1,000 IU/day) supplementation of vitamin D for preterm infants (Table 5). In all studies, serum 25(OH)D levels after supplementation were significantly higher in the high-dose versus low-dose group. ${ }^{114-}$ 119) The prevalence of VDD was also significantly lower in the high-dose group. ${ }^{114,116,118,120)}$ Two studies showed that the highdose group experienced bone density benefits. ${ }^{117,120)}$ One study reported that the high-dose group had better growth results, ${ }^{120}$ ) consistent with the results of a recent meta-analysis. ${ }^{121)}$ Despite the benefits of high-dose supplementation, concern persists about the adverse effects of excess vitamin D intake, such as hypercalciuria or nephrocalcinosis. ${ }^{14,116,122)}$ The risk of vitamin $\mathrm{D}$ overdose could be increased upon achieving a total dose of $1,000 \mathrm{IU} /$ day, combining supplements and diets, especially in neonates with a birth weight $<1,000$ g. ${ }^{123)}$

Based on the results of the trials mentioned above, a vitamin D intake of $800 \mathrm{IU} /$ day can be considered in preterm infants along with biochemical monitoring. The total vitamin $\mathrm{D}$ intake of $800 \mathrm{IU} /$ day should include the vitamin D content of human milk fortifier or formula as well as vitamin D supplementation. The vitamin D contents of human milk fortifiers and formulas commonly fed in Korea are summarized in Table 6.

\section{Three sources of vitamin D}

\section{Sun exposure}

Ultraviolet radiation B from sun exposure is a major source of vitamin D. Several studies reported a positive correlation between sun exposure and serum vitamin D levels in breastfed infants. ${ }^{124,125)}$ Meena et al. ${ }^{125)}$ suggested a minimum 30-minute weekly afternoon sunlight exposure between 10:00 AM and 3:00 PM over $40 \%$ of the body area (infant clothed in a diaper in the prone position) for at least 16 weeks to achieve sufficient

Table 6. Vitamin D contents of formulas and foods

\begin{tabular}{lc}
\hline Formula and foods & IU per serving \\
\hline Human milk fortifier, 1 pack & $30-37.5$ \\
Preterm formula, $100 \mathrm{~mL}$ & $56-128$ \\
Term formula, $100 \mathrm{~mL}$ & $33.2-52$ \\
Cod liver oil, 1 table spoon (1 table spoon=15 mL) & 1,360 \\
Salmon, cooked, $100 \mathrm{~g}$ & 360 \\
Mackerel, cooked $100 \mathrm{~g}$ & 345 \\
Sardine, oiled and canned, $100 \mathrm{~g}$ & 270 \\
Eel, cooked, $100 \mathrm{~g}$ & 200 \\
Milk, vitamin D fortified, $200 \mathrm{~mL}$ & 100 \\
Egg, 1 large (vitamin D is found in yolk) & 25 \\
Mushroom, $100 \mathrm{~g}$ & 20
\end{tabular}

Source of vitamin D contents of foods: National Health Information Portal, Korea Disease Control and Prevention Agency. http://health.kdca.go.kr/ healthinfo. vitamin D levels by 6 months of age. ${ }^{125)}$ However, despite intense sun exposure, $90 \%$ of infants continued to have vitamin D insufficiency and required supplementation. ${ }^{126)}$

The harmful effects of ultraviolet rays must also be considered despite their beneficial effects associated with vitamin $\mathrm{D}$ synthesis. It is known to increase the risk of photodamage and melanoma or non-melanoma skin cancer, especially in the Caucasian population. ${ }^{127)}$ The AAP recommends that infants younger than 6 months be kept out of direct sunlight. ${ }^{128,129)}$ Outdoor activities should be planned to minimize peak-intensity midday sun exposure (10:00 AM to 4:00 PM). ${ }^{128)}$ Current guidelines recommend that vitamin $\mathrm{D}$ requirements be met through supplementation rather than deliberate sun exposure in infants. ${ }^{127,128)}$

\section{Food sources of vitamin $D$}

Vitamin D is present in a preactive form in several foods. Foods rich in vitamin $\mathrm{D}$ are summarized in Table 6. Vitamin $\mathrm{D}_{3}$ is found in foods of animal origin, such as blue fatty fish, egg yolk, liver, and milk. Vitamin $\mathrm{D}_{2}$ is found in small amounts in food of vegetable origin and wild mushrooms. ${ }^{130)}$

\section{Vitamin D supplementation}

As mentioned earlier, $400 \mathrm{IU} /$ day of vitamin D supplementation for breastfed infants is recommended by most international guidelines. This supplement should be cholecalciferol, vitamin $\mathrm{D}_{3}$, due to its superior absorption. ${ }^{102)}$ However, there were major concerns about parental compliance, ${ }^{131)}$ pediatrician practices, ${ }^{63)}$ and incorrect dosing risk. ${ }^{132,133)}$ In 2020, a systematic review reported on infant intermittent vitamin D supplementation as an alternative to daily supplementation. ${ }^{134)}$ The doses varied from a single bolus of 30,000-600,000 IU, an intermittent bolus of $50,000 \mathrm{IU} \times 3$ to $600,000 \mathrm{IU} \times 2$, and $1,400 \mathrm{IU} / \mathrm{wk}$ from postnatal 7 days to 6 months. Overall, bolus dosing $(>50,000$ IU) achieves higher $25(\mathrm{OH}) \mathrm{D}$ repletion rates earlier than daily dosing, but it is likely to have similar efficacy at preventing VDD in later infancy. Considering the findings of trials to date, the evidence remains too weak to recommend intermittent vitamin D supplementation as an alternative to daily supplementation.

\section{Conclusion}

Breastfed infants are vulnerable to VDD because of the low vitamin $\mathrm{D}$ content of breast milk, restricted sunlight exposure, and limited access to natural dietary sources of vitamin D. These infants are at major risk for VDD rickets, which appears to have re-emerged on a global scale. Most international guidelines recommend that exclusively or partially breastfed infants be supplemented with $400 \mathrm{IU} /$ day of vitamin D during their first year of life. However, domestic studies of the status and guidelines for vitamin $\mathrm{D}$ in breastfed infants are insufficient. Therefore, further research with a larger number of subjects is needed to clarify the status of VDD in Korean infants and 
guidelines to ensure adequate vitamin D status.

\section{Footnotes}

Conflicts of interest: No potential conflict of interest relevant to this article was reported.

Funding: This study received no specific grant from any funding agency in the public, commercial, or not-for-profit sectors.

\section{ORCID:}

Ju Sun Heo (D) https://orcid.org/0000-0001-8928-289X Young Min Ahn (1) https://orcid.org/0000-0002-1697-8041

Ai-Rhan Ellen Kim (1) https://orcid.org/0000-0002-9859-3021

Son Moon Shin (D) https://orcid.org/0000-0002-3743-3307

\section{References}

1. Thorne-Lyman A, Fawzi WW. Vitamin D during pregnancy and maternal, neonatal and infant health outcomes: a systematic review and metaanalysis. Paediatr Perinat Epidemiol 2012;26:75-90.

2. Xiao J, He W. The immunomodulatory effects of vitamin D drops in children with recurrent respiratory tract infections. Am J Transl Res 2021;13:1750-6.

3. Panfili FM, Roversi M, D'Argenio P, Rossi P, Cappa M, Fintini D. Possible role of vitamin D in COVID-19 infection in pediatric population. J Endocrinol Invest 2021;44:27-35.

4. Knihtilä HM, Stubbs BJ, Carey VJ, Laranjo N, Chu SH, Kelly RS, et al. Low gestational vitamin $\mathrm{D}$ level and childhood asthma are related to impaired lung function in high-risk children. J Allergy Clin Immunol 2021;148:110-9.e9.

5. Sharif A, Haddad Kashani H, Sharif MR. Association of 25-hydroxy vitamin $\mathrm{D}$ with asthma and its severity in children: a case-control study. Clin Mol Allergy 2020;18:7.

6. Singh N, Kamble D, Mahantshetti NS. Effect of vitamin D supplementation in the prevention of recurrent pneumonia in under-five children. Indian J Pediatr 2019;86:1105-11.

7. Shin YH, Ha EK, Kim JH, Yon DK, Lee SW, Sim HJ, et al. Serum vitamin $\mathrm{D}$ level is associated with smell dysfunction independently of aeroallergen sensitization, nasal obstruction, and the presence of allergic rhinitis in children. Pediatr Allergy Immunol 2021;32:116-23.

8. Chen YS, Mirzakhani H, Lu M, Zeiger RS, O'Connor GT, Sandel MT, et al. The association of prenatal vitamin D sufficiency with aeroallergen sensitization and allergic rhinitis in early childhood. J Allergy Clin Immunol Pract 2021;9:3788-96.e3.

9. Briceno Noriega D, Savelkoul HFJ. Vitamin D and allergy susceptibility during gestation and early life. Nutrients 2021;13:1015.

10. Tiazhka OV, Selska ZV. Application of vitamin D in different dosage to treat children with allergic diseases. Wiad Lek 2020;73:1377-83.

11. Cristi F, Perez-Mateluna G, Vera-Kellet C, Silva-Valenzuela S, Iturriaga C, Hoyos-Bachiloglu R, et al. Vitamin D modulates the allergic phenotype of dendritic cells in children with atopic dermatitis. Exp Dermatol 2019; 28:308-11

12. Cai B, Luo X, Zhang P, Luan Y, Cai X, He X. Effect of vitamin D supplementation on markers of cardiometabolic risk in children and adolescents: a meta-analysis of randomized clinical trials. Nutr Metab Cardiovasc Dis 2021;31:2800-14

13. Xie H, Min M, Guo S, Xian Y, Yang F, Wang X, et al. Impact of vitamin D and vitamin D receptor on risk of cardiovascular diseases in children and adolescents with obesity in Sichuan, China: a cross-sectional study. Ann Nutr Metab 2020;76:396-404.
14. Milagres LC, Filgueiras MS, Rocha NP, Suhett LG, de Albuquerque FM, Juvanhol LL, et al. Cutoff point estimation for serum vitamin D concentrations to predict cardiometabolic risk in Brazilian children. Eur J Clin Nutr 2020;74:1698-706.

15. Lopez-Mayorga A, Hauger H, Petersen RA, Vogel U, Damsgaard CT, Lauritzen L. Vitamin D-related genes and cardiometabolic markers in healthy children: a Mendelian randomisation study. Br J Nutr 2020; 123:1138-47.

16. Hauger H, Laursen RP, Ritz C, Mølgaard C, Lind MV, Damsgaard CT. Effects of vitamin D supplementation on cardiometabolic outcomes in children and adolescents: a systematic review and meta-analysis of randomized controlled trials. Eur J Nutr 2020;59:873-84.

17. Garfein J, Flannagan KS, Gahagan S, Burrows R, Lozoff B, Villamor E. Vitamin D status in infancy and cardiometabolic health in adolescence. Am J Clin Nutr 2020;113:104-12.

18. Colak R, Anil M, Yasar F, Rahmi Bakiler A, Pirgon O, Helvaci M, et al. Metabolic disturbances and cardiovascular risk factors in obese children with vitamin D deficiency. Arch Pediatr 2020;27:140-5.

19. Censani M, Hammad HT, Christos PJ, Schumaker T. Vitamin D deficiency associated with markers of cardiovascular disease in children with obesity. Glob Pediatr Health 2018;5:2333794x17751773.

20. McClorry S, Slupsky CM, Lind T, Karlsland Åkeson P, Hernell O, Öhlund I. Effectiveness of vitamin D supplementation in Swedish children may be negatively impacted by BMI and serum fructose. J Nutr Biochem 2020;75:108251.

21. Flores Ruelas Y, Del Toro Equihua M, Alejandra Jiménez Solís N, Baltazar Rodríguez LM, Delgado Enciso I, Sánchez Ramírez CA. Vitamin D status and its relation to insulin resistance in a Mexican pediatric population. $J$ Pediatr Endocrinol Metab 2020;33:481-6.

22. Corica D, Zusi C, Olivieri F, Marigliano M, Piona C, Fornari E, et al. Vitamin D affects insulin sensitivity and $\beta$-cell function in obese nondiabetic youths. Eur J Endocrinol 2019;181:439-50.

23. Jackmann N, Mäkitie O, Harila-Saari A, Gustafsson J, Nezirevic Dernroth D, Frisk P. Vitamin D status in children with leukemia, its predictors, and association with outcome. Pediatr Blood Cancer 2020;67:e28163.

24. Revuelta Iniesta R, Rush R, Paciarotti I, Rhatigan EB, Brougham FHM, McKenzie JM, et al. Systematic review and meta-analysis: prevalence and possible causes of vitamin D deficiency and insufficiency in pediatric cancer patients. Clin Nutr 2016;35:95-108.

25. Institute of Medicine (US) Committee to Review Dietary Reference Intakes for Vitamin D and Calcium. Dietary reference intakes for calcium and vitamin D. In: Ross AC, Taylor CL, Yaktine AL, Del Valle HB, editors. Dietary reference intakes for calcium and vitamin D. Washington, DC: National Academies Press (US), 2011.

26. Holick MF, Clark MB. The photobiogenesis and metabolism of vitamin D. Fed Proc 1978;37:2567-74.

27. Bikle DD, Nemanic MK, Gee E, Elias P. 1,25-Dihydroxyvitamin D3 production by human keratinocytes. Kinetics and regulation. J Clin Invest 1986;78:557-66.

28. Bär M, Domaschke D, Meye A, Lehmann B, Meurer M. Wavelengthdependent induction of CYP24A1-mRNA after UVB-triggered calcitriol synthesis in cultured human keratinocytes. J Invest Dermatol 2007;127: 206-13.

29. DeLuca HF. Overview of general physiologic features and functions of vitamin D. Am J Clin Nutr 2004;80:1689S-1696S.

30. Okazaki R, Ozono K, Fukumoto S, Inoue D, Yamauchi M, Minagawa $\mathrm{M}$, et al. Assessment criteria for vitamin D deficiency/insufficiency in Japan - proposal by an expert panel supported by Research Program of Intractable Diseases, Ministry of Health, Labour and Welfare, Japan, The Japanese Society for Bone and Mineral Research and The Japan Endocrine Society [Opinion]. Endocr J 2017;64:1-6.

31. Paxton GA, Teale GR, Nowson CA, Mason RS, McGrath JJ, Thompson MJ, et al. Vitamin D and health in pregnancy, infants, children and adolescents in Australia and New Zealand: a position statement. Med J Aust 2013;198:142-3.

32. Braegger C, Campoy C, Colomb V, Decsi T, Domellof M, Fewtrell M, et al. Vitamin D in the healthy European paediatric population. J Pediatr 
Gastroenterol Nutr 2013;56:692-701.

33. Munns CF, Shaw N, Kiely M, Specker BL, Thacher TD, Ozono K, et al. Global consensus recommendations on prevention and management of nutritional rickets. J Clin Endocrinol Metab 2016;101:394-415.

34. World Health Organization. Infant and young child feeding. Geneva (Switzerland): WHO; 2020 [cited 2021 Mar 8]. Available from: https:// www.who.int/en/news-room/fact-sheets/detail/infant-and-young-childfeeding.

35. Gartner LM, Greer FR. Prevention of rickets and vitamin D deficiency: new guidelines for vitamin D intake. Pediatrics 2003;111:908-10.

36. The Korean Nutrition Society. 2020 Dietary Reference Intakes for Korean [Internet]. Seoul (Korea): The Korean Nutrition Society; 2020 [cited 2021 Mar 10]. Available from: http://www.kns.or.kr/FileRoom/ FileRoom_view.asp? $\mathrm{idx}=108 \&$ BoardID $=\mathrm{Kdr}$

37. Tsugawa N, Nishino M, Kuwabara A, Ogasawara H, Kamao M, Kobayashi S, et al. Comparison of Vitamin D and 25-hydroxyvitamin D concentrations in human breast milk between 1989 and 2016-2017. Nutrients 2021;13:573.

38. Wagner CL, Hollis BW. Early-Life Effects of Vitamin D: a focus on pregnancy and lactation. Ann Nutr Metab 2020;76 Suppl 2:16-28.

39. Halfon M, Phan O, Teta D. Vitamin D: a review on its effects on muscle strength, the risk of fall, and frailty. Biomed Res Int 2015;2015:953241.

40. Mailhot G, White JH. Vitamin D and immunity in infants and children. Nutrients 2020;12:1233.

41. Wrzosek M, Łukaszkiewicz J, Wrzosek M, Jakubczyk A, Matsumoto H, Piątkiewicz P, et al. Vitamin D and the central nervous system. Pharmacol Rep 2013;65:271-8.

42. Michos ED, Cainzos-Achirica M, Heravi AS, Appel LJ. Vitamin D, calcium supplements, and implications for cardiovascular health: JACC focus seminar. J Am Coll Cardiol 2021;77:437-49.

43. Saggese G, Vierucci F, Boot AM, Czech-Kowalska J, Weber G, Camargo $\mathrm{CA} \mathrm{Jr}$, et al. Vitamin D in childhood and adolescence: an expert position statement. Eur J Pediatr 2015;174:565-76.

44. Bae YJ, Kratzsch J. Vitamin D and calcium in the human breast milk. Best Pract Res Clin Endocrinol Metab 2018;32:39-45.

45. Holick MF, Binkley NC, Bischoff-Ferrari HA, Gordon CM, Hanley DA, Heaney RP, et al. Evaluation, treatment, and prevention of vitamin D deficiency: an Endocrine Society clinical practice guideline. J Clin Endocrinol Metab 2011;96:1911-30.

46. Płudowski P, Karczmarewicz E, Bayer M, Carter G, Chlebna-Sokół D, Czech-Kowalska J, et al. Practical guidelines for the supplementation of vitamin D and the treatment of deficits in Central Europe - recommended vitamin $\mathrm{D}$ intakes in the general population and groups at risk of vitamin D deficiency. Endokrynol Pol 2013;64:319-27.

47. Society for Adolescent Health and Medicine. Recommended vitamin D intake and management of low vitamin D status in adolescents: a position statement of the Society for Adolescent Health and Medicine. J Adolesc Health 2013;52:801-3.

48. Golden NH, Abrams SA. Optimizing bone health in children and adolescents. Pediatrics 2014;134:e1229-43.

49. EFSA Panel on Dietetic Products, Nutrition and Allergies (NDA). Dietary reference values for vitamin D. EFSA J 2016;14:4547.

50. Haq A, Wimalawansa SJ, Pludowski P, Anouti FA. Clinical practice guidelines for vitamin D in the United Arab Emirates. J Steroid Biochem Mol Biol 2018;175:4-11.

51. Siafarikas A, Simm P, Zacharin M, Jefferies C, Lafferty AR, Wheeler BJ, et al. Global consensus on nutritional rickets: implications for Australia. J Paediatr Child Health 2020;56:841-6.

52. Rosen CJ. Clinical practice. Vitamin D insufficiency. N Engl J Med 2011; 364:248-54.

53. Mithal A, Wahl DA, Bonjour JP, Burckhardt P, Dawson-Hughes B, Eisman JA, et al. Global vitamin D status and determinants of hypovitaminosis D. Osteoporos Int 2009;20:1807-20.

54. The Korean Society of Pediatric Endocrinology Clinical Guidelines. Clinical practice guidelines for bone health in children and adolescents 2019. Seoul (Korea): Korean Society of Pediatric Endocrinology, 2019.

55. Dawodu A, Tsang RC. Maternal vitamin D status: effect on milk vitamin
D content and vitamin D status of breastfeeding infants. Adv Nutr 2012; 3:353-61.

56. Parian-de los Angeles E, Retoriano K, Arnaldo H, Ronquillo-Nolasco ME, Urtula R. Vitamin D status of breastfed Filipino infants aged less than 6 months in an urban community. Pediatr Gastroenterol Hepatol Nutr 2021;24:403-12.

57. Said NA, Kamenwa RW, Limbe MS, Okumu MO, Macharia WM. Prevalence of vitamin D deficiency in exclusively breastfed infants at a tertiary healthcare facility in Nairobi, Kenya. Arch Endocrinol Metab 2021;64:726-34.

58. Trivedi M, Faridi MMA, Aggarwal A, Madhu SV, Malhotra RK. Oral vitamin D supplementation to mothers during lactation-effect of $25(\mathrm{OH})$ $\mathrm{D}$ concentration on exclusively breastfed infants at 6 months of age: a randomized double-blind placebo-controlled trial. Breastfeed Med 2020; $15: 237-45$

59. Terashita S, Nakamura T, Igarashi N. Longitudinal study on the effectiveness of vitamin D supplements in exclusively breast-fed infants. Clin Pediatr Endocrinol 2017;26:215-22.

60. Haugen J, Ulak M, Chandyo RK, Henjum S, Thorne-Lyman AL, Ueland PM, et al. Low prevalence of vitamin D insufficiency among Nepalese infants despite high prevalence of vitamin D insufficiency among their mothers. Nutrients 2016;8:825.

61. Salameh K, Al-Janahi NS, Reedy AM, Dawodu A. Prevalence and risk factors for low vitamin $\mathrm{D}$ status among breastfeeding mother-infant dyads in an environment with abundant sunshine. Int J Womens Health 2016; 8:529-35.

62. Wheeler BJ, Taylor BJ, Herbison P, Haszard JJ, Mikhail A, Jones S, et al. High-dose monthly maternal cholecalciferol supplementation during breastfeeding affects maternal and infant vitamin D status at 5 months postpartum: a randomized controlled trial. J Nutr 2016;146:1999-2006.

63. Dawodu A, Zalla L, Woo JG, Herbers PM, Davidson BS, Heubi JE, et al. Heightened attention to supplementation is needed to improve the vitamin $\mathrm{D}$ status of breastfeeding mothers and infants when sunshine exposure is restricted. Matern Child Nutr 2014;10:383-97.

64. Wall CR, Grant CC, Jones I. Vitamin D status of exclusively breastfed infants aged 2-3 months. Arch Dis Child 2013;98:176-9.

65. Jain V, Gupta N, Kalaivani M, Jain A, Sinha A, Agarwal R. Vitamin D deficiency in healthy breastfed term infants at 3 months $\&$ their mothers in India: seasonal variation \& determinants. Indian J Med Res 2011; 133:267-73.

66. Agarwal N, Faridi MM, Aggarwal A, Singh O. Vitamin D status of term exclusively breastfed infants and their mothers from India. Acta Paediatr 2010;99:1671-4.

67. Creo AL, Thacher TD, Pettifor JM, Strand MA, Fischer PR. Nutritional rickets around the world: an update. Paediatr Int Child Health 2017;37: 84-98.

68. Kang YS, Kim JH, Ahn EH, Yoo EG, Kim MK. Iron and vitamin D status in breastfed infants and their mothers. Korean J Pediatr 2015;58:283-7.

69. Choi YJ, Kim MK, Jeong SJ. Vitamin D deficiency in infants aged 1 to 6 months. Korean J Pediatr 2013;56:205-10.

70. Kim MJ, Na B, No SJ, Han HS, Jeong EH, Lee W, et al. Nutritional status of vitamin D and the effect of vitamin D supplementation in Korean breast-fed infants. J Korean Med Sci 2010;25:83-9.

71. Park MJ, Namgung R, Kim DH, Tsang RC. Bone mineral content is not reduced despite low vitamin $\mathrm{D}$ status in breast milk-fed infants versus cow's milk based formula-fed infants. J Pediatr 1998;132:641-5.

72. Hollis BW, Roos BA, Draper HH, Lambert PW. Vitamin D and its metabolites in human and bovine milk. J Nutr 1981;111:1240-8.

73. Reeve LE, Chesney RW, DeLuca HF. Vitamin D of human milk: identification of biologically active forms. Am J Clin Nutr 1982;36:122-6.

74. Stoutjesdijk E, Schaafsma A, Nhien NV, Khor GL, Kema IP, Hollis BW, et al. Milk vitamin D in relation to the 'adequate intake' for 0-6-month-old infants: a study in lactating women with different cultural backgrounds, living at different latitudes. Br J Nutr 2017;118:804-12.

75. Thandrayen K, Pettifor JM. Maternal vitamin D status: implications for the development of infantile nutritional rickets. Rheum Dis Clin North Am 2012;38:61-79. 
76. Taylor SN, Wagner CL, Hollis BW. Vitamin D supplementation during lactation to support infant and mother. J Am Coll Nutr 2008;27:690701.

77. Ala-Houhala M, Koskinen T, Parviainen MT, Visakorpi JK. 25-Hydroxyvitamin D and vitamin D in human milk: effects of supplementation and season. Am J Clin Nutr 1988;48:1057-60.

78. við Streym S, Højskov CS, Møller UK, Heickendorff L, Vestergaard P, Mosekilde L, et al. Vitamin D content in human breast milk: a 9-mo follow-up study. Am J Clin Nutr 2016;103:107-14.

79. Oberson JM, Bénet S, Redeuil K, Campos-Giménez E. Quantitative analysis of vitamin $\mathrm{D}$ and its main metabolites in human milk by super. critical fluid chromatography coupled to tandem mass spectrometry. Anal Bioanal Chem 2020;412:365-75.

80. Nguyen MTT, Kim J, Lee H, Won S, Kim Y, Jung JA, et al. A comparison of vitamin and lutein concentrations in breast milk from four Asian countries. Nutrients 2020;12:1794.

81. Sakurai T, Furukawa M, Asoh M, Kanno T, Kojima T, Yonekubo A. Fatsoluble and water-soluble vitamin contents of breast milk from Japanese women. J Nutr Sci Vitaminol (Tokyo. 2005;51:239-47.

82. Kamao M, Tsugawa N, Suhara Y, Wada A, Mori T, Murata K, et al. Quantification of fat-soluble vitamins in human breast milk by liquid chromatography-tandem mass spectrometry. J Chromatog B 2007;859: 192-200.

83. Jan Mohamed HJ, Rowan A, Fong B, Loy SL. Maternal serum and breast milk vitamin D levels: findings from the Universiti Sains Malaysia Pregnancy Cohort Study. PLoS One 2014;9:e100705.

84. Cancela L, Le Boulch N, Miravet L. Relationship between the vitamin D content of maternal milk and the vitamin D status of nursing women and breast-fed infants. JEndocrinol 1986;110:43-50.

85. Basile LA, Taylor SN, Wagner CL, Horst RL, Hollis BW. The effect of high-dose vitamin D supplementation on serum vitamin D levels and milk calcium concentration in lactating women and their infants. Breastfeed Med 2006;1:27-35.

86. Hollis BW, Wagner CL. Assessment of dietary vitamin D requirements during pregnancy and lactation. Am J Clin Nutr 2004;79:717-26.

87. Wagner CL, Hulsey TC, Fanning D, Ebeling M, Hollis BW. High-dose vitamin D3 supplementation in a cohort of breastfeeding mothers and their infants: a 6-month follow-up pilot study. Breastfeed Med 2006; 1:59-70.

88. Wagner C. Current concepts in vitamin D requirements for mother and her breastfeeding infant. Breastfeed Med 2012;7:561-2.

89. WHO (World Health Organization). Vitamin and mineral requirements in human nutrition, 2nd ed. Geneva (Switzerland): WHO, 2004.

90. Nordic Council of Ministers, Nordic Council of Ministers Secretariat. Nordic Nutrition Recommendations 2012: Integrating nutrition and physical activity. 5th ed. Copenhagen (Denmark): Nordisk Ministerråd, 2014:627.

91. Hollis BW, Wagner CL. Vitamin D requirements during lactation: highdose maternal supplementation as therapy to prevent hypovitaminosis D for both the mother and the nursing infant. Am J Clin Nutr 2004;80: 1752S-8S.

92. Specker BL, Tsang RC, Hollis BW. Effect of race and diet on human-milk vitamin D and 25-hydroxyvitamin D. Am J Dis Child 1985;139:1134-7.

93. Schoenmakers I, Pettifor JM, Peña-Rosas JP, Lamberg-Allardt C, Shaw $\mathrm{N}$, Jones KS, et al. Prevention and consequences of vitamin D deficiency in pregnant and lactating women and children: a symposium to prioritise vitamin D on the global agenda. J Steroid Biochem Mol Biol 2016;164:156-60.

94. Oberhelman SS, Meekins ME, Fischer PR, Lee BR, Singh RJ, Cha SS, et al. Maternal vitamin D supplementation to improve the vitamin D status of breast-fed infants: a randomized controlled trial. Mayo Clin Proc 2013;88:1378-87.

95. March KM, Chen NN, Karakochuk CD, Shand AW, Innis SM, von Dadelszen P, et al. Maternal vitamin $\mathrm{D}_{3}$ supplementation at $50 \mu \mathrm{g} / \mathrm{d}$ protects against low serum 25 -hydroxyvitamin $\mathrm{D}$ in infants at $8 \mathrm{wk}$ of age: a randomized controlled trial of 3 doses of vitamin $\mathrm{D}$ beginning in gestation and continued in lactation. Am J Clin Nutr 2015;102:402-10.
96. Tan ML, Abrams SA, Osborn DA. Vitamin D supplementation for term breastfed infants to prevent vitamin D deficiency and improve bone health. Cochrane Database Syst Rev 2020;12:Cd013046.

97. Chandy DD, Kare J, Singh SN, Agarwal A, Das V, Singh U, et al. Effect of vitamin D supplementation, directly or via breast milk for term infants, on serum 25 hydroxyvitamin $\mathrm{D}$ and related biochemistry, and propensity to infection: a randomised placebo-controlled trial. Br J Nutr 2016;116:52-8.

98. Naik P, Faridi MMA, Batra P, Madhu SV. Oral supplementation of parturient mothers with vitamin $\mathrm{D}$ and its effect on 25OHD status of exclusively breastfed infants at 6 months of age: a double-blind randomized placebo controlled trial. Breastfeed Med 2017;12:621-8.

99. Roth DE. Maternal postpartum high-dose vitamin D3 supplementation (6400 IU/day) or conventional infant vitamin D3 supplementation (400 IU/day) lead to similar vitamin D status of healthy exclusively/fully breastfeeding infants by 7 months of age. Evid Based Med 2016;21:75.

100. Hollis BW, Wagner CL, Howard CR, Ebeling M, Shary JR, Smith PG, et al. Maternal versus infant vitamin $\mathrm{D}$ supplementation during lactation: a randomized controlled trial. Pediatrics 2015;136:625-34.

101. European Food Safety Authority (EFSA). Scientific opinion on the tolerable upper intake level of vitamin D. EFSA panel on dietetic products, nutrition and allergies (NDA) [Internet]. Parma (Italy): EFSA; 2012 [cited 2021 Feb 28]. Available from https://efsa.onlinelibrary.wiley. com/doi/epdf/10.2903/j.efsa.2012.2813.

102. Taylor SN. ABM Clinical Protocol \#29: iron, zinc, and vitamin D supplementation during breastfeeding. Breastfeed Med 2018;13:398404.

103. Wagner CL, Greer FR. Prevention of rickets and vitamin D deficiency in infants, children, and adolescents. Pediatrics 2008;122:1142-52.

104. American Academy of Pediatrics. Statement of endorsement. Dietary reference intakes for calcium and vitamin D. Pediatrics 2012;130:e1424.

105. Vidailhet M, Mallet E, Bocquet A, Bresson JL, Briend A, Chouraqui JP, et al. Vitamin D: still a topical matter in children and adolescents. A position paper by the Committee on Nutrition of the French Society of Paediatrics. Arch Pediatr 2012;19:316-28.

106. Tanaka K, Kuwabara A, Tsugawa N. Vitamin D in the dietary reference intakes for Japanese (DRIs) 2020. J Nutr Sci Vitaminol (Tokyo) 2020; 66:497-501.

107. Yorifuji J, Yorifuji T, Tachibana K, Nagai S, Kawai M, Momoi T, et al. Craniotabes in normal newborns: the earliest sign of subclinical vitamin D deficiency. J Clin Endocrinol Metab 2008;93:1784-8.

108. Abrams SA. Calcium and vitamin d requirements of enterally fed preterm infants. Pediatrics 2013;131:e1676-83.

109. Zung A, Topf-Olivestone C, Shinwell ES, Hofi L, Juster-Reicher A, Flidel-Rimon O. Reassessing vitamin D supplementation in preterm infants: a prospective study and review of the literature. J Pediatr Endocrinol Metab 2020;33:1273-81.

110. Agostoni C, Buonocore G, Carnielli VP, De Curtis M, Darmaun D, Decsi T, et al. Enteral nutrient supply for preterm infants: commentary from the European Society of Paediatric Gastroenterology, Hepatology and Nutrition Committee on Nutrition. J Pediatr Gastroenterol Nutr 2010; 50:85-91.

111. Chen W, Yang C, Chen H, Zhang B. Risk factors analysis and prevention of metabolic bone disease of prematurity. Medicine (Baltimore) 2018; 97:e12861.

112. Pieltain C, de Halleux V, Senterre T, Rigo J. Prematurity and bone health. World Rev Nutr Diet 2013;106:181-8.

113. Lapillonne A, Bronsky J, Campoy C, Embleton N, Fewtrell M, Fidler Mis $\mathrm{N}$, et al. Feeding the late and moderately preterm infant: a position paper of the European Society for Paediatric Gastroenterology, Hepatology and Nutrition Committee on Nutrition. J Pediatr Gastroenterol Nutr 2019;69:259-70.

114. Natarajan CK, Sankar MJ, Agarwal R, Pratap OT, Jain V, Gupta N, et al. Trial of daily vitamin D supplementation in preterm infants. Pediatrics 2014;133:e628-34.

115. Fort P, Salas AA, Nicola T, Craig CM, Carlo WA, Ambalavanan N. A comparison of 3 vitamin $\mathrm{D}$ dosing regimens in extremely preterm 
infants: a randomized controlled trial. J Pediatr 2016;174:132-8.e1.

116. Tergestina M, Rebekah G, Job V, Simon A, Thomas N. A randomized double-blind controlled trial comparing two regimens of vitamin D supplementation in preterm neonates. J Perinatol 2016;36:763-7.

117. Anderson-Berry A, Thoene M, Wagner J, Lyden E, Jones G, Kaufmann $\mathrm{M}$, et al. Randomized trial of two doses of vitamin D3 in preterm infants $<32$ weeks: dose impact on achieving desired serum 25(OH)D3 in a NICU population. PLoS One 2017;12:e0185950.

118. Bozkurt O, Uras N, Sari FN, Atay FY, Sahin S, Alkan AD, et al. Multi-dose vitamin $\mathrm{D}$ supplementation in stable very preterm infants: prospective randomized trial response to three different vitamin D supplementation doses. Early Hum Dev 2017;112:54-9.

119. Abdel-Hady H, Yahia S, Megahed A, Mosbah A, Seif B, Nageh E, et al. Mediators in preterm infants with late-onset sepsis: a randomized controlled trial. J Pediatr Gastroenterol Nutr 2019;68:578-84.

120. Mathur NB, Saini A, Mishra TK. Assessment of adequacy of supplementation of vitamin $\mathrm{D}$ in very low birth weight preterm neonates: a randomized controlled trial. J Trop Pediatr 2016;62:429-35.

121. Yang Y, Li Z, Yan G, Jie Q, Rui C. Effect of different doses of vitamin D supplementation on preterm infants - an updated meta-analysis. J Matern Fetal Neonatal Med 2018;31:3065-74.

122. Cho SY, Park HK, Lee HJ. Efficacy and safety of early supplementation with $800 \mathrm{IU}$ of vitamin D in very preterm infants followed by underlying levels of vitamin D at birth. Ital J Pediatr 2017;43:45.

123. Justyna CK. Mineral and nutritional requirements of preterm infant. Semin Fetal Neonatal Med 2020;25:101071.

124. Oktaria V, Graham SM, Triasih R, Soenarto Y, Bines JE, Ponsonby $\mathrm{AL}$, et al. The prevalence and determinants of vitamin $\mathrm{D}$ deficiency in Indonesian infants at birth and six months of age. PLoS One 2020; 15:e0239603.

125. Meena P, Dabas A, Shah D, Malhotra RK, Madhu SV, Gupta P. Sunlight exposure and vitamin D status in breastfed infants. Indian Pediatr 2017;54:105-11.

126. Karthikeyan G, Monish GK. Going solar is good but caution needed! Indian Pediatr 2017;54:511.

127. Jindal AK, Gupta A, Vinay K, Bishnoi A. Sun exposure in children: balancing the benefits and harms. Indian Derm Online J 2020;11:94-8.

128. Balk SJ. Ultraviolet radiation: a hazard to children and adolescents. Pediatrics 2011;127:e791-817.

129. Paller AS, Hawk JL, Honig P, Giam YC, Hoath S, Mack MC, et al. New insights about infant and toddler skin: implications for sun protection. Pediatrics 2011;128:92-102.

130. Aguilar-Shea AL. Vitamin D, the natural way. Clin Nutr ESPEN 2021; 41:10-2.

131. Simon AE, Ahrens KA. Adherence to vitamin D intake guidelines in the United States. Pediatrics 2020;145:e20193574.

132. Bilbao NA. Vitamin D toxicity in young breastfed infants: report of 2 cases. Glob Pediatr Health 2017;4:2333794x17731695.

133. Cantrell L, Hogen E. Vitamin D overdosage in an infant from nonprescription vitamin D drops. Am J Health Syst Pharm 2015;72:1262-3.

134. O'Callaghan KM, Taghivand M, Zuchniak A, Onoyovwi A, Korsiak J, Leung M, et al. Vitamin D in breastfed infants: systematic review of alternatives to daily supplementation. Adv Nutr 2020;11:144-59.

135. World Health Organization. Vitamin D supplementation in infants. Geneva (Switzerland): World Health Organization, 2014.

How to cite this article: Heo JS, Ahn YM, Kim AR, Shin SM; for the Korean Society of Breastfeeding Medicine. Breastfeeding and vitamin D. Clin Exp Pediatr 2022;65:41829. https://doi.org/10.3345/cep.2021.00444 